\title{
A Study of the Distributions of Two Endangered Sea Skaters Halobates matsumurai Esaki and Asclepios shiranui (Esaki) (Hemiptera: Gerridae: Halobatinae) with Special Reference to Their Strategies to Cope with Tidal Currents
}

\author{
Terumi Ikawa $\mathbb{D}^{1},{ }^{1}$ Yuichi Nozoe, ${ }^{2}$ Natsuko Yamashita, ${ }^{1}$ \\ Namiko Nishimura, ${ }^{2}$ Satoshi Ohnoki, ${ }^{1}$ Kyoko Yusa, ${ }^{2}$ Sugihiko Hoshizaki, ${ }^{3}$ \\ Masayuki Komaba, ${ }^{2}$ and Akihiro Kawakubo ${ }^{2}$ \\ ${ }^{1}$ Faculty of Humanities, Morioka University, 808 Sunakomi, Takizawa, Iwate 020-0605, Japan \\ ${ }^{2}$ Kujukushima Research Group, Kujukushima Pearl Sea Resort, 1008 Kashimae, Sasebo, Nagasaki 858-0922, Japan \\ ${ }^{3}$ Graduate School of Agricultural and Life Sciences, The University of Tokyo, 1-1-1 Yayoi, Bunkyo, Tokyo 113-8657, Japan \\ Correspondence should be addressed to Terumi Ikawa; trmi@pop02.odn.ne.jp
}

Received 30 November 2017; Accepted 1 February 2018; Published 18 April 2018

Academic Editor: Ai-Ping Liang

Copyright (C) 2018 Terumi Ikawa et al. This is an open access article distributed under the Creative Commons Attribution License, which permits unrestricted use, distribution, and reproduction in any medium, provided the original work is properly cited.

\begin{abstract}
There exist surprisingly few marine insects, most of which are confined to the intertidal zone. Halobates is the only genus to have some oceanic species along with some coastal species. Among the coastal sea skaters, that is, genus Halobates and its close relative, genus Asclepios, there are variations in their affinity for the shore. We have studied the distributions of two endangered Japanese sea skaters, Halobates matsumurai and Asclepios shiranui in Kujukushima, where they cooccur in coves. To compare their survival strategies at sea, we especially noted differences in their distributions along the shore during high and low tides. The results show that $A$. shiranui tended to remain along the shore during low tide. This species appeared to cling to the shore against the ebb current and to stay in the protected coves. By contrast, $H$. matsumurai tended to leave the shore during low tide. Notably, some adults were found skating outside the coves. The strategy of $H$. matsumurai appeared to be leaving with the ebb current even beyond the coves, thereby using more resources and enlarging its habitat. Some such coastal Halobates might have acquired the ability to live on the open ocean clearly independent of the shoreline.
\end{abstract}

\section{Introduction}

Compared to the unparalleled prosperity of the insects in the terrestrial world, there are surprisingly few in the sea $[1,2]$. Of more than one million extant insect species, only a few thousand are marine. Most of them are confined to the intertidal zone. A small number of species, such as the marine chironomid or gerrid, live in the neritic zone [3]. Only five species of genus Halobates (Hemiptera: Gerridae) have successfully colonized the open ocean [4-7]. In addition to these five oceanic species, Halobates comprises some 40 coastal species. Genus Halobates and its close relative, genus Asclepios, are totally wingless throughout their life stages and live on the sea surface, hence known as sea skaters.
One of the most intriguing questions regarding these sea skaters is which strategies have enabled them to colonize the sea, especially the open oceans. Phylogenetic studies based on molecular and morphological markers suggest that Asclepios and Halobates diverged from their limnic sister group, Metrocorini, and extended their habitats to the seacoasts; some of them even established themselves in the open ocean [8-13].

Coastal species heavily depend on resources from the seashore $[6,7]$. There they find what they need to subsist, such things as terrestrial insects falling on the sea surface to use as food, existing rocks or plants for egg-laying substrates, or even overhanging vegetation for protection from UV radiation. Thus, it is vital for them to remain nearshore, 


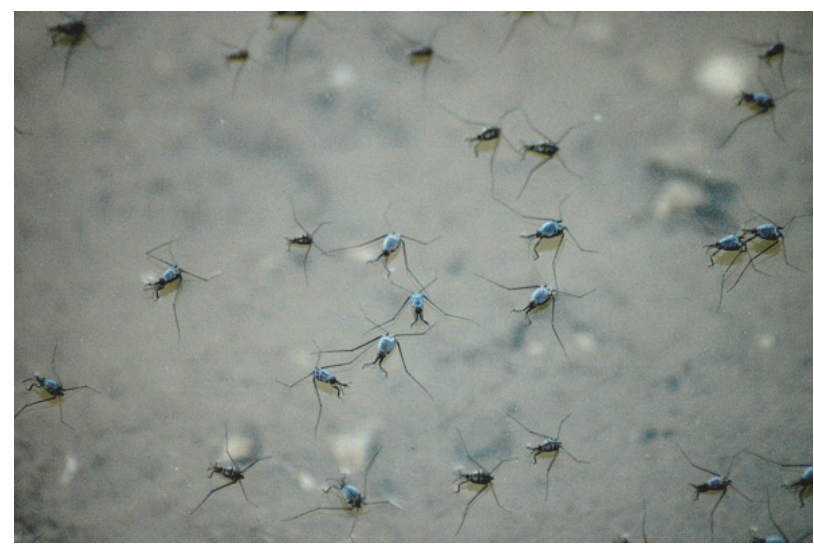

(a)

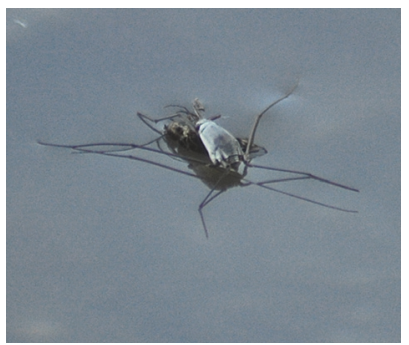

(b)

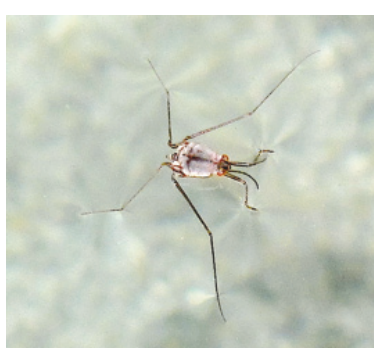

(c)

Figure 1: (a) Aggregation of sea skaters (photo by Y. Nozoe). (b) Adult of H. matsumurai (photo by N. Nishimura). (c) Adult of A. shiranui (photo by Y. Nozoe).

coping with the tidal currents, especially the ebb currents which act to carry them away to the open sea. By contrast, the oceanic species spend their whole life on the ocean surface completely apart from the shore. It is suspected that adaptation to the open ocean might have evolved gradually among coastal sea skaters, developing their tolerance for more exposed habitats [9]. In fact, variations in their affinity for the shore are recognized among coastal sea skaters $[7,13-$ 15]. Further study of variations among coastal sea skaters may shed some light on how they have shifted their adaptive strategies from the shore to the open sea.

Keeping the above in mind, we have studied the distributions of two endangered Japanese sea skaters, Halobates matsumurai Esaki and Asclepios shiranui (Esaki) (Hemiptera: Gerridae: Halobatinae) in the Kujukushima area in Sasebo, Kyushu, Japan, where the two species often cooccur in small coves along jagged coasts. We especially noted differences in their distributions along the shore during high and low tides. We then compared their distributions and have discussed the differences in their strategies to cope with tidal currents.

H. matsumurai and A. shiranui are now designated as threatened II (VU) by the Japanese Ministry of the Environment due to the drastic decrease in their populations [16]. Shortly after this study was completed, collection of these vulnerable species was banned in a major portion of their habitat in Kyushu, including the Kujukushima area. Thus, we had a rare opportunity, now prohibited, to collect and study these fascinating creatures.

\section{Materials and Methods}

2.1. Study Area. H. matsumurai (Figure 1(b)) and A. shiranui (Figure 1(c)) are found in the coastal areas of Kujukushima, which consists of more than 200 islands studded off the north coast of Sasebo, Kyushu [17-20]. They cooccur in small coves along uninhabited jagged coastlines, many of which were inaccessible from the land. We carried out this study at one of these coves, visiting by boat under the provision of the Kujukushima Aquarium. This cove is ca. $300 \mathrm{~m}$ long and ca. $80 \mathrm{~m}$ wide at the opening during high tide. $H$. matsumurai and A. shiranui were observed to form mixedspecies aggregations along the shore (Figure 1(a)) $[19,21]$.

2.2. Samplings of Sea Skaters during High and Low Tides. Samplings of sea skaters were conducted during high tide (highest tidal level: $315 \mathrm{~cm}$ at 9:45 am) and low tide (lowest tidal level: $50 \mathrm{~cm}$ at 3:50 pm) on September 17, 2008. We collected them either from a boat or from shore using insect nets with an opening of $25 \mathrm{~cm}$ in diameter.

At high tide, water covered the cove completely reaching almost to the edge of the vegetation on the shore (Figure 2(a)). The inner half of the cove was accessible only by canoe from which it was too dangerous to swing the net. Hence, no sampling was taken there and only observations from the canoe were made. At the outer half of the cove, samplings were taken from the boat (A1 and A2 in the innermost part of the cove where samplings were possible; B1 and B2 at 


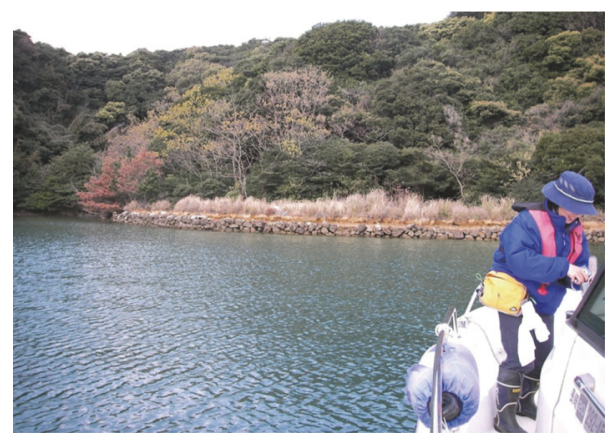

(a)

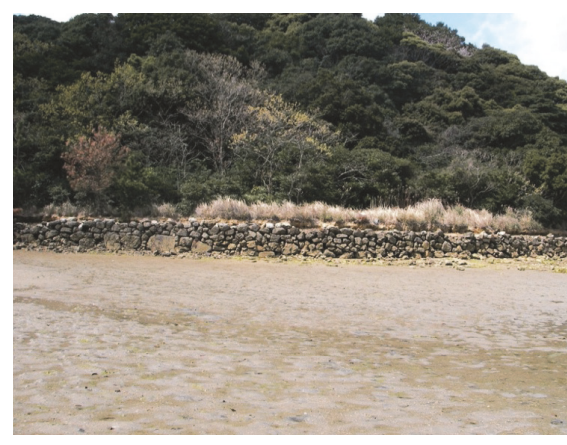

(b)

Figure 2: Study site during high tide (a) and during low tide (b).

the middle of the cove; $\mathrm{C} 1$ and $\mathrm{C} 2$ near the opening of the cove) as shown in Figure 3(a). At each site, we sampled one aggregation of sea skaters.

During low tide, a tidal sand flat appeared around the inner half of the cove. Many tidal pools were formed on the tidal flat (Figure 2(b)). Rocky stretches of sandstone emerged along both shores near the opening of the cove. Samplings were taken from shore at the 12 sites (Figure 4(a)): TF1 and TF2 towards the inner end of the tidal flat; TF3 and TF4 at the middle of the tidal flat; and TF5 and TF6 on the tidal flat near the waterfront. Also, samplings were taken from the cove area: at D1 and D2 along the shore closest to the tidal flat; E1 and $\mathrm{E} 2$ along the mid-shore of the cove; and F1 and F2 along the shore near the opening of the cove. At each site on the tidal flat (TF1 TF6), we sampled from one tidal pool. At the other sites (D1 F2), we sampled one aggregation per site.

To examine the composition of species and ages of an aggregation in relation to the distance from the waterfront, we took another sampling during low tide (lowest tidal level: $6 \mathrm{~cm}$ at 3:00 pm) on August 1,2008. We collected individuals of one aggregation at each of the seven sites (G-1 G-7), which were located at varying distances from the waterfront edge of the tidal flat towards the mouth of the cove (Figure 5).

The insects collected were preserved in $99 \%$ ethanol and identified in the laboratory as to species, developmental stage, and sex.

2.3. Observations of the Entire Cove Area during High and Low Tides. To confirm the existence of sea skaters (adults, nymphs, and eggs [21]) in the entire area of the sea surface and shoreline of the cove, we made intensive observation by human vision either from canoe or on foot during low tide on September 16 and during high tide on September 18, 2008. No sampling was conducted.

\section{Results}

3.1. Distributions of Sea Skaters at the Shoreline during High and Low Tide. During high tide, H. matsumurai was present at all the sampling sites (Figure 3(b)). The total number of H. matsumurai caught was 101: adults 62; old nymphs 29 (4th instar 17, 5th instar 12); young nymphs 10 (1st and 2nd instar 0,3 rd instar 10), respectively. A. shiranui was also caught at all sampling sites except site B1 (Figure 3(c)). The total number of A. shiranui captured was 57: adults 13; old nymphs 33 (4th instar 18, 5th instar 15); and young nymphs 11 (1st instar 0 , 2nd instar 1, 3rd instar 10), respectively. The majority of individuals caught were adults and older nymphs for both species.

During low tide, the total number of $H$. matsumurai caught was 28: adults 3; old nymphs 17 (4th instar 13, 5th instar 4); and young nymphs 8 (1st instar 4, 2nd instar 3, 3rd instar 1), respectively (Figure 4(b)). The total number of A. shiranui captured was 456; adults 11; old nymphs 178 (4th instar 101, 5th instar 77); young nymphs 267 (1st instar 142, 2nd instar 95, 3rd instar 30), respectively (Figure 4(c)). The number of nymphs was higher than that of the adults for both species.

During low tide, as for $H$. matsumurai, only 3 nymphs were caught in two tidal pools (TF5 and TF6) near the waterfront (Figure 4(b)). On the other hand, numerous nymphs of $A$. shiranui were present in all the tidal pools sampled (Figure 4(c)). No adults of either species were collected in tidal pools. In general, the younger nymphs of A. shiranui tended to stay in tidal pools and along the shore toward the inner end of the cove, while the older nymphs and adults had a tendency to stay near the opening of the cove. Compared to A. shiranui, the number of $H$. matsumurai caught was very low and it was hard to note such a tendency.

3.2. Distributions of Sea Skaters in Relation to Distance from Waterfront Edge of Tidal Flat. The percentages of individuals of each developmental stage per aggregation at sampling sites G-1 G-7 are shown in Figure 5. The total numbers of $A$. shiranui and $H$. matsumurai of each aggregation were 41 and 0 at G-1, 50 and 0 at G-2, 59 and 1 at G-3, 275 and 1 at G-4, 70 and 0 at G-5, 200 and 19 at G-6, and 67 and 12 at G-7, respectively. In the tidal pool (G-1) and near the waterfront edge (G-2), the aggregations consisted only of young nymphs of $A$. shiranui. The greater the distance from the waterfront edge, the higher the percentage of older nymphs and adults of $A$. shiranui found. We also noted that in three aggregations, G-3, G-6, and G-7, which were rather close to the opening of the cove, nymphs and/or adults of $H$. matsumurai were both present.

3.3. Observation on the Whole Area of the Cove during High and Low Tides. Through visual inspection, only adults of $H$. matsumurai could be recognized by their characteristic 


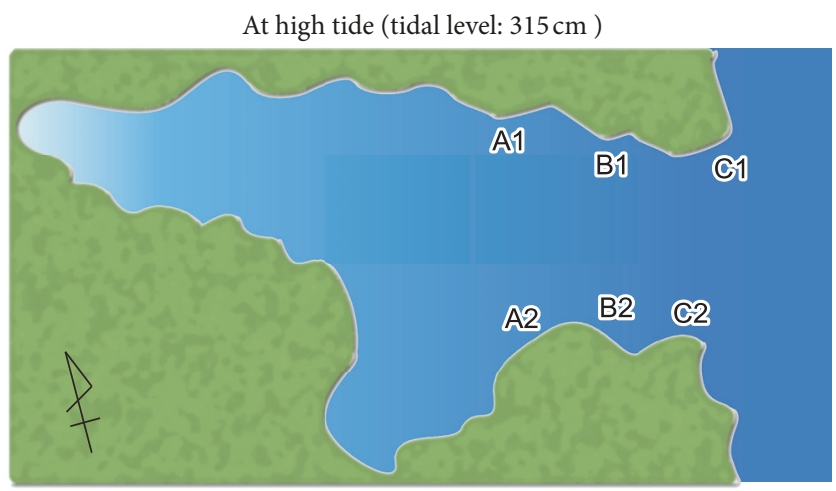

(a)

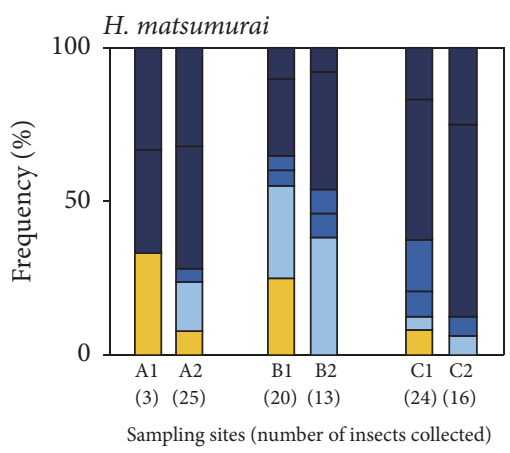

(b)

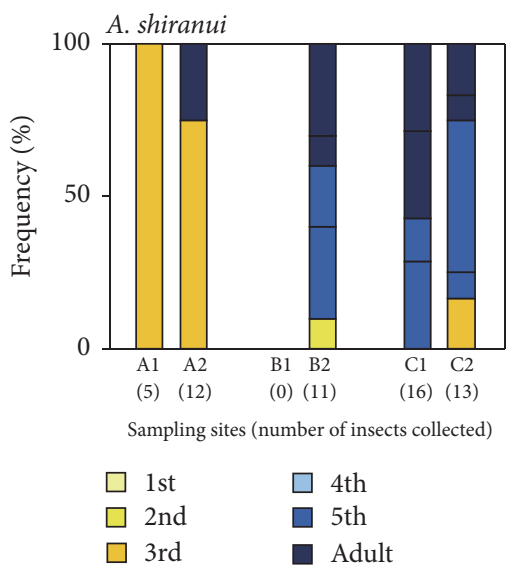

(c)

Figure 3: (a) Sampling sites (A1, A2, B1, B2, C1, and C2) at high tide. (b) Composition of developmental stages of H. matsumurai and (c) of A. shiranui at each sampling site.

whitish body coloration. As for all other individuals, species or ages were nearly indistinguishable. During high tide, in the inner part of the cove, we found a number of adults of $H$. matsumurai and some unidentifiable individuals on the sea surface along the shore. Sea skaters forming sparse aggregations were present mainly along the shore in the middle and outer part of the cove. A small number of sea skaters, including adults of $H$. matsumurai, were observed off shore. Notably, the adults of $H$. matsumurai were seen outside the cove as well. During low tide, many nymphs, the large part of which were probably A. shiranui, were found in tidal pools formed on the tidal sand flat. On the sea surface along the shore, many nymphs and adults were present in dense aggregations. A small number of sea skaters were also seen off the shore of the cove. Single adults and copulating pairs of $H$. matsumurai were occasionally observed sliding along the shore and also offshore, within the cove and outside of it. Newly laid eggs of $H$. matsumurai were found on the sandstones along the shore. No sea skaters were found on the shore during either high or low tides. 


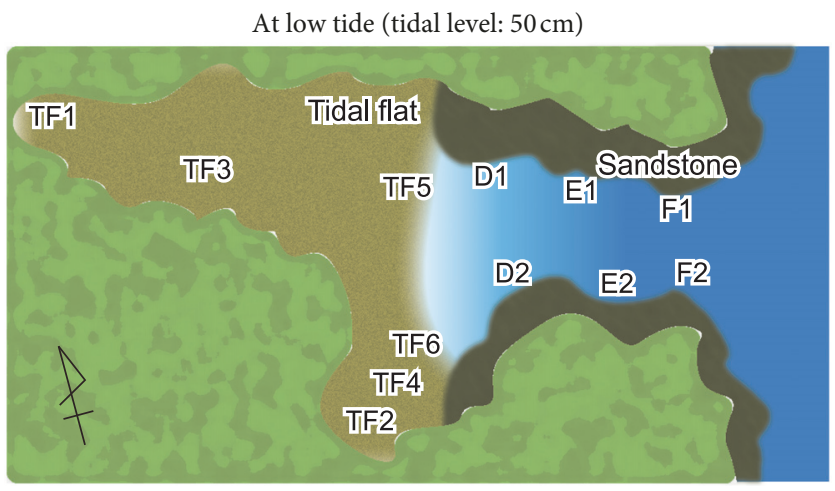

(a)

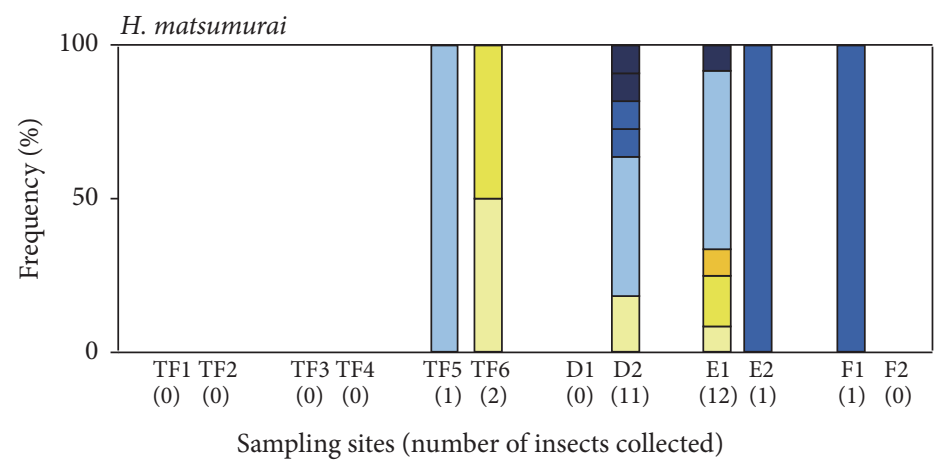

(b)

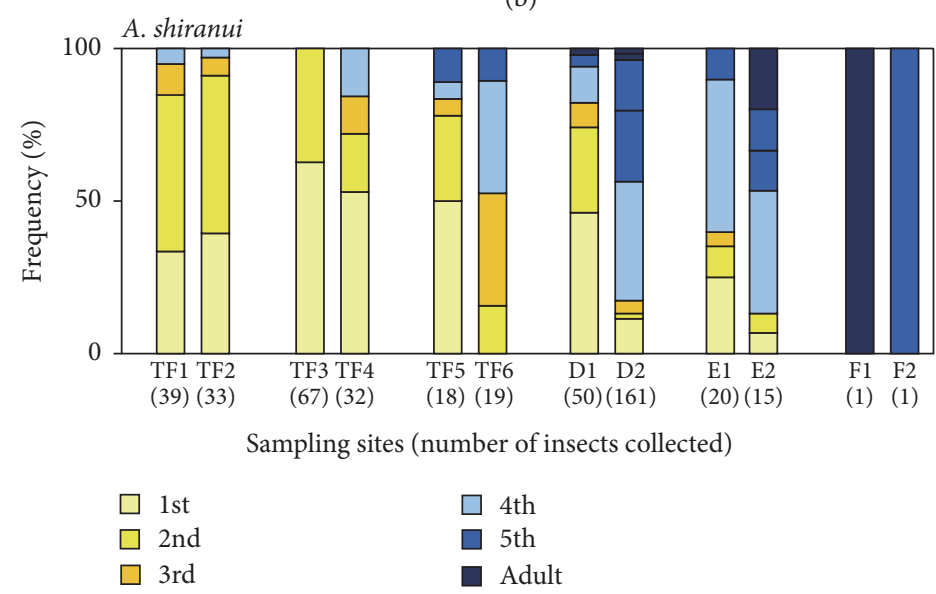

(c)

FigURE 4: (a) Sampling sites (TF1, TF2, TF3, TF4, TF5, TF6, D1, D2, E1, E2, F1, and F2) at low tide. (b) Composition of developmental stages of H. matsumurai and (c) of A. shiranui at each sampling site.

\section{Discussion}

During high tide, the total number of $H$. matsumurai sampled (101 individuals) was nearly twice as much as that of $A$. shiranui (57 individuals). On the other hand, during low tide, the total number of $A$. shiranui caught (456 individuals) was 16 times as much as that of $H$. matsumurai (28 individuals). These results show that, compared to A. shiranui, H. matsumurai had a greater tendency to remain along the shore during high tide, whereas, conversely, A. shiranui tended to remain along the shore and also in the tide pools during low tide. It is not certain where $A$. shiranui had gone during high tide or $H$. matsumurai during low tide, because, in spite of intensive observation of the whole area of the cove, not many sea skaters were found off shore. It remains of special interest to us to understand the whereabouts of so many young nymphs of $A$. shiranui (267 individuals), which had appeared during low tide yet seemed to be absent during high tide. The most plausible explanation at present would be that many of the sea skaters when spread out offshore, especially the small nymphs, were beyond recognition by the unaided human eye. Only by sweeping a neuston net over the 


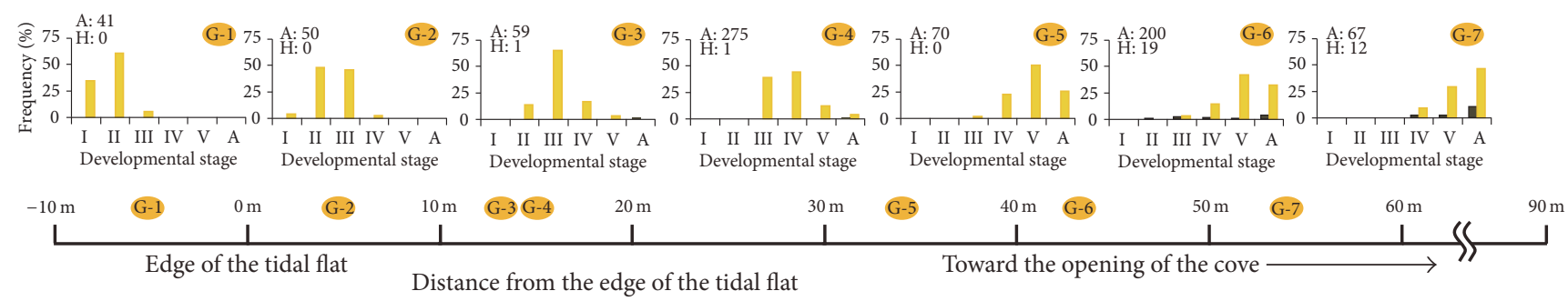

A. shiranui

- H. matsumurai

FIGURE 5: Composition of developmental stages of A. shiranui and H.matsumurai of each aggregation (G1-G7) formed on tidal pools or along the seashore at varying distances from the waterfront edge of the tidal flat. A: the total number of $A$. shiranui and $\mathrm{H}$ : the total number of $H$. matsumurai at each aggregation.

surface could one try to estimate the densities of sea skaters in the whole area of the cove. However, application of such a massive sampling method would be out of the question for these endangered insects.

Considering that more $H$. matsumurai stayed along the shore during high tide than during low tide, it may be that this species left the shore with the ebb current and returned toward shore on the flood tide. In fact, adults of $H$. matsumurai were observed sliding on the sea surface offshore and even quite a distance away beyond the coves. Thus, skating with the tidal currents, they would be able to use resources outside the coves and also would be able to disperse themselves among various coves. As a matter of fact, the distribution range of $H$. matsumurai is reported to be much wider than that of $A$. shiranui in the north coast of Kyushu, including the Kujukushima area [18]. More individuals of $H$. matsumurai were observed along the shore during high tide. It is presumed that they had been feeding on terrestrial insects found on the sea surface. Adult females may have been looking for oviposition sites because many newly laid eggs were found on the sandstones along the shore. By contrast, A. shiranui appears to cling to the shore during ebb tide. This species seems to prefer more protected habitats than other sea skaters as they were often found even in waterways of salt farms [22]. A. shiranui might not be as strong a skater as H. matsumurai which can return after sliding far from shore. Hence, A. shiranui might spread out offshore only during high tide when the water flow comes towards the shore. The strong affinity of $A$. shiranui for the shore is also confirmed by the fact that, during low tide, smaller nymphs tended to remain around the inner part of the cove where the possibility of being washed away by the ebb current would most likely be lower than around the outer part of the cove (Figures 4(c) and $5)$.

H. matsumurai's strategy to survive in the marine environment appears quite different from that of $A$. shiranui. Although $H$. matsumurai depends on resources from the land like A. shiranui $[19,21,23]$, they disperse themselves away from the shore during low tide. The adults can venture out of the cove without resisting the ebb currents. The merits of being able to move with tidal currents would be twofold: firstly $H$. matsumurai can therefore find and use more resources than by staying within a cove; secondly, it can enlarge its habitat range, leaving the original cove, crossing a more open body of water, and finding a new cove. Furthermore, some such coastal Halobates might have acquired the ability to live on the open ocean clearly independent of the shoreline. This might be one of the ways in which coastal Halobates have shifted their survival strategy from the shore to the open ocean.

\section{Conflicts of Interest}

The authors declare that there are no conflicts of interest regarding the publication of this paper.

\section{Acknowledgments}

The authors give heartfelt thanks to the members of Kujukushima Aquarium for the assistance during the field survey. They are indebted to A. Chiba, M. Iwabe, and R. Takeya for their help with identification of sea skaters and drawing pictures, to Sasebo Coast Guard Office for offering the tidal data, and to L. Cheng, H. Okabe, and Y. Suzuki for helpful discussions. Special thanks are due to S. Unher for editing and improving the paper. This study was partly supported by the Academic Grant of Morioka University for the year of 2008 (to Terumi Ikawa).

\section{References}

[1] L. Cheng and J. H. Frank, "Marine insects and their reproduction," Oceanography and Marine Biology, vol. 31, pp. 479-506, 1993.

[2] L. Cheng, "Marine insects," in Encyclopedia of Insects, V. H. Resh and R. T. Cardé, Eds., pp. 600-604, Academic Press, San Diego, CA, USA, 2nd edition, 2009.

[3] J. V. Ward, Aquatic Insect Ecology. 1. Biology and Habitat, John Wiley and Sons, New York, NY, USA, 1992.

[4] N. M. Andersen and J. T. Polhemus, "Water-striders (Hemiptera: Gerridae, Veliidae, etc.)," in Marine Insects, L. Cheng, Ed., pp. 187-224, 1976.

[5] L. Cheng, "Biology of Halobates (Heteroptera: Gerridae)," Annual Review of Entomology, vol. 31, pp. 111-135, 1985.

[6] N. M. Andersen and L. Cheng, "The marine insect Halobates (Heteroptera: Gerridae): biology, adaptations, distribution, and 
phylogeny," Oceanography and Marine Biology, vol. 42, pp. 119179, 2005.

[7] T. Ikawa, H. Okabe, and L. Cheng, "Skaters of the seas-comparative ecology of nearshore and pelagic Halobates species (Hemiptera: Gerridae), with special reference to Japanese species," Marine Biology Research, vol. 8, no. 10, pp. 915-936, 2012.

[8] L. Cheng, "Biogeography and phylogeny of the sea-skater Halobates," Chinese Journal of Oceanology and Limnology, vol. 7, no. 3, pp. 233-239, 1989.

[9] N. M. Andersen, "Marine insects: genital morphology, phylogeny and evolution of sea skaters, genus Halobates (Hemiptera: Gerridae)," Zoological Journal of the Linnean Society, vol. 103, no. 1, pp. 21-60, 1991.

[10] N. M. Andersen, "The evolution of marine insects: phylogenetic, ecological and geographical aspects of species diversity in marine water striders," Ecography, vol. 22, no. 1, pp. 98-111, 1999.

[11] N. M. Andersen, A. Farma, A. Minelli, and G. Piccoli, "A fossil Halobates from the Mediterranean and the origin of sea skaters (Hemiptera, Gerridae)," Zoological Journal of the Linnean Society, vol. 112, no. 4, pp. 479-489, 1994.

[12] N. M. Andersen, L. Cheng, J. Damgaard, and F. A. H. Sperling, "Mitochondrial DNA sequence variation and phylogeography of oceanic insects (Hemiptera: Gerridae: Halobates spp.)," Marine Biology, vol. 136, no. 3, pp. 421-430, 2000.

[13] N. M. Andersen and T. A. Weir, "The sea skaters, genus Halobates Eschscholtz (Hemiptera: Gerridae), or Australia: taxonomy, phylogeny and zoogeography," Invertebrate Taxonomy, vol. 8, no. 4, pp. 861-909, 1994.

[14] D. A. Polhemus, "Heteroptera of Aldabra Atoll and nearby islands, western Indian Ocean, part 1. Marine Heteroptera (Insecta): Gerridae, Veliidae, Hermatobatidae, Saldidae and Omaniidae, with notes on ecology and insular zoogeography," Atoll Research Bulletin, vol. 345, pp. 1-16, 1990.

[15] D. A. Polhemus and J. T. Polhemus, "The marine Heteroptera of far eastern New Guinea and adjacent archipelagoes (Insecta, Gerromorpha)," Denesia, vol. 19, no. 50, pp. 927-982, 2006.

[16] Association of Wildlife Research and EnVision, "Search System of Japanese Red Data” (Japanese), 2017, http://jpnrdb.com/ index.html, http://jpnrdb.com/search.php? mode=key\&amp;k= 07\&amp;t=\&amp;cd=\&amp;q=\%A5\%B7\%A5\%ED\%A5\%A6\% A5\%DF\%A5\%A2\%A5\%E1\%A5\%F3\%A5\%DC and http:// jpnrdb.com/search.php? mode=key\&amp;q=\%A5\%B7\%A5\% AA\%A5\%A2\%A5\%E1\%A5\%F3\%A5\%DC.

[17] Y. Kawachino, "New localities of Asclepios shiranui and Halobates matsumurai in Nagasaki Prefecture," Transaction of Nagasaki Biological Society, vol. 53, p. 26, 2001 (Japanese).

[18] M. Hayashi and S. Miyamoto, "Distribution and habitat of Asclepios shiranui, with distributional notes on some other coastal marine skaters (Heteroptera: Gerridae and Veliidae) in northern Kyushu, Japan,” Rostria, vol. 51, pp. 1-20, 2003 (Japanese).

[19] F. Yone, T. Matsuo, A. Kawakubo, F. Saijo, and Y. Mori, "Distribution of coastal sea skaters in southern Kujukusima," Transactions of the Nagasaki Biological Society, vol. 57, p. 1, 2004 (Japanese).

[20] T. Ikawa, "Survey of Kuroshima and Takashima, two major islands of Kujukushima as habitats of the threatened marine insects, Halobates matsumurai Esaki and Asclepios shiranui (Esaki) (Hemiptera: Gerridae)," Journal of Morioka University, vol. 27, pp. 27-33, 2010.
[21] T. Ikawa, Y. Nozoe, N. Yamashita et al., "Life histories of two endangered sea skaters Halobates matsumurai Esaki and Asclepios shiranui (Esaki) (Hemiptera: Gerridae: Halobatinae)," Psyche, vol. 2012, Article ID 261071, 7 pages, 2012.

[22] S. Miyamoto, Gerridae, Series 1, Part 3 of of Insecta Japonica, Hokuryukan Publishing, Tokyo, Japan, 1961.

[23] S. Matsuo, Y. Nozoe, and T. Ohtani, "Preliminary study of the oviposition site of sea skater Asclepios shiranui (Esaki) (Hemiptera: Gerridae)," Transactions of the Nagasaki Biological Society, vol. 72, pp. 13-15, 2013 (Japanese). 


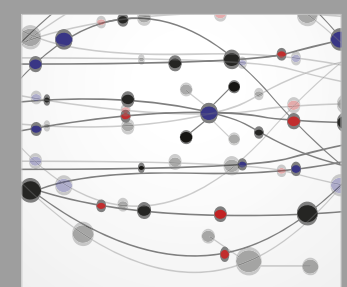

The Scientific World Journal
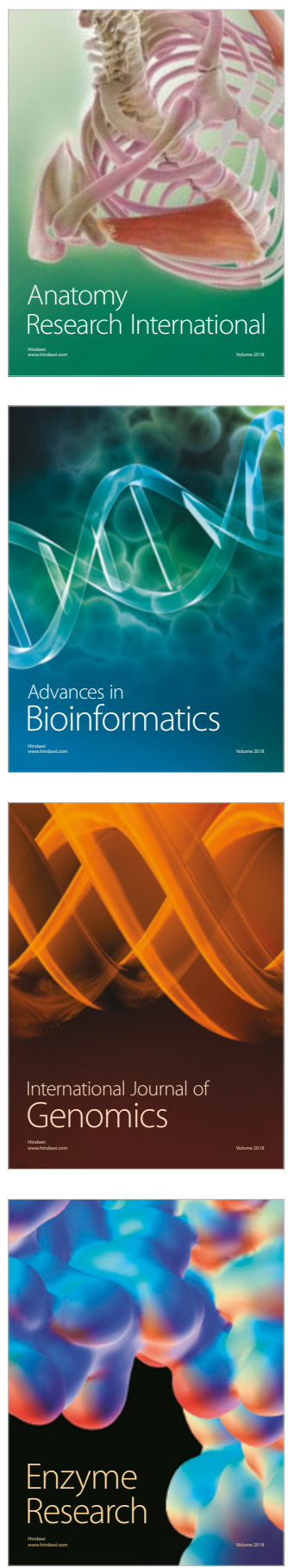
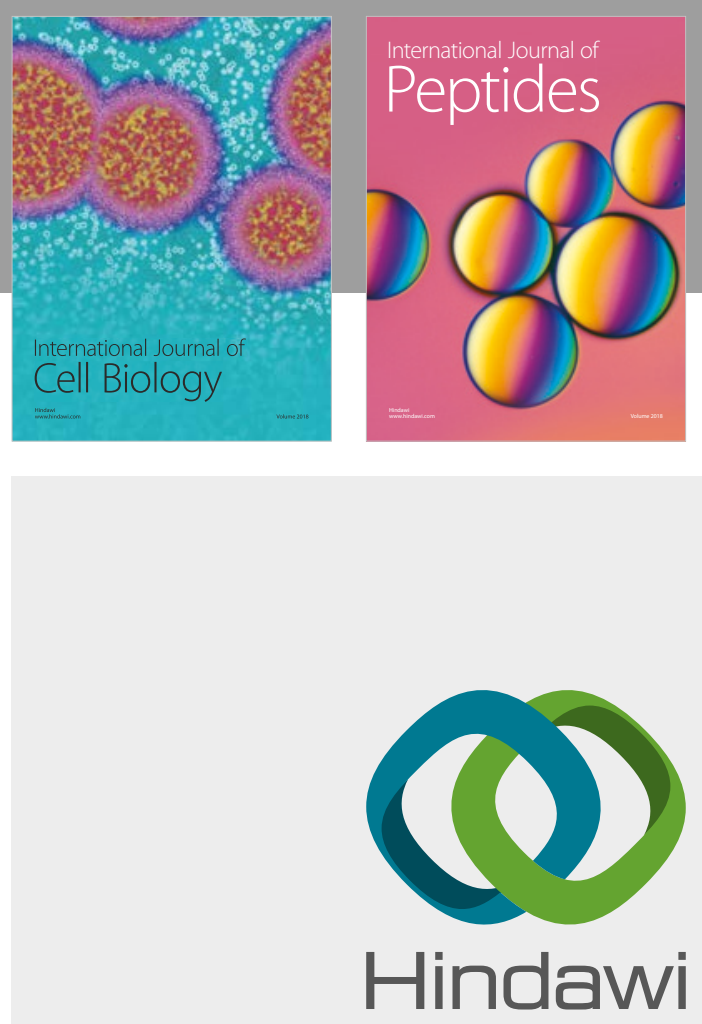

Submit your manuscripts at

www.hindawi.com
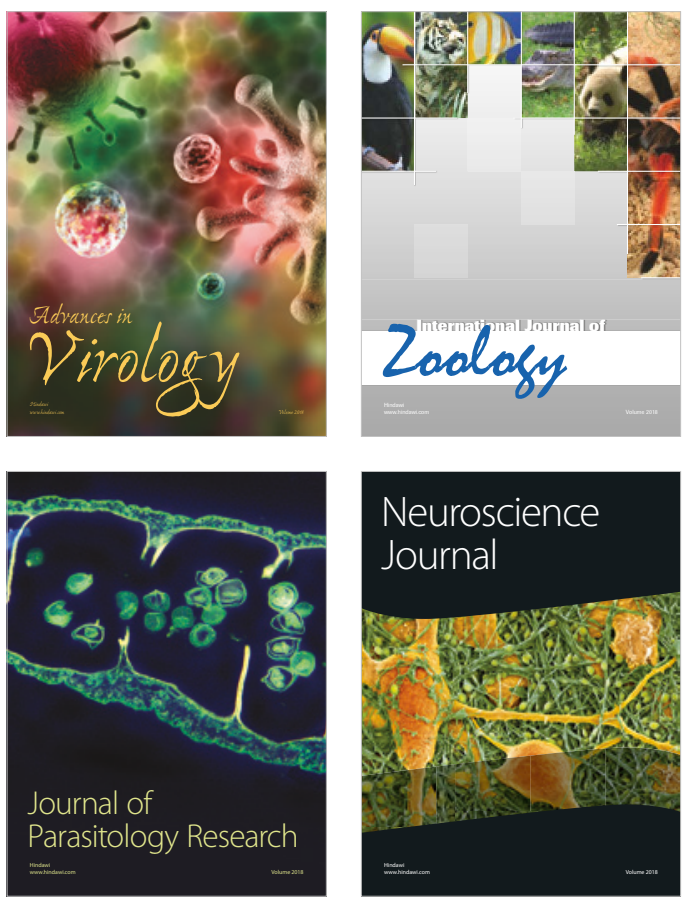
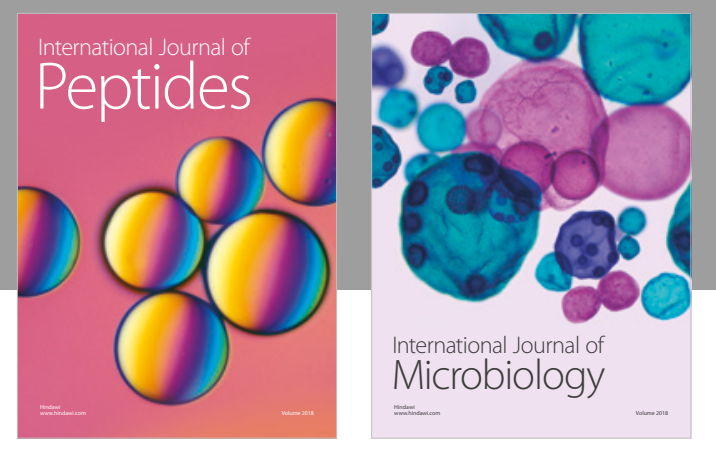

nternational Journal of Microbiology
Journal of
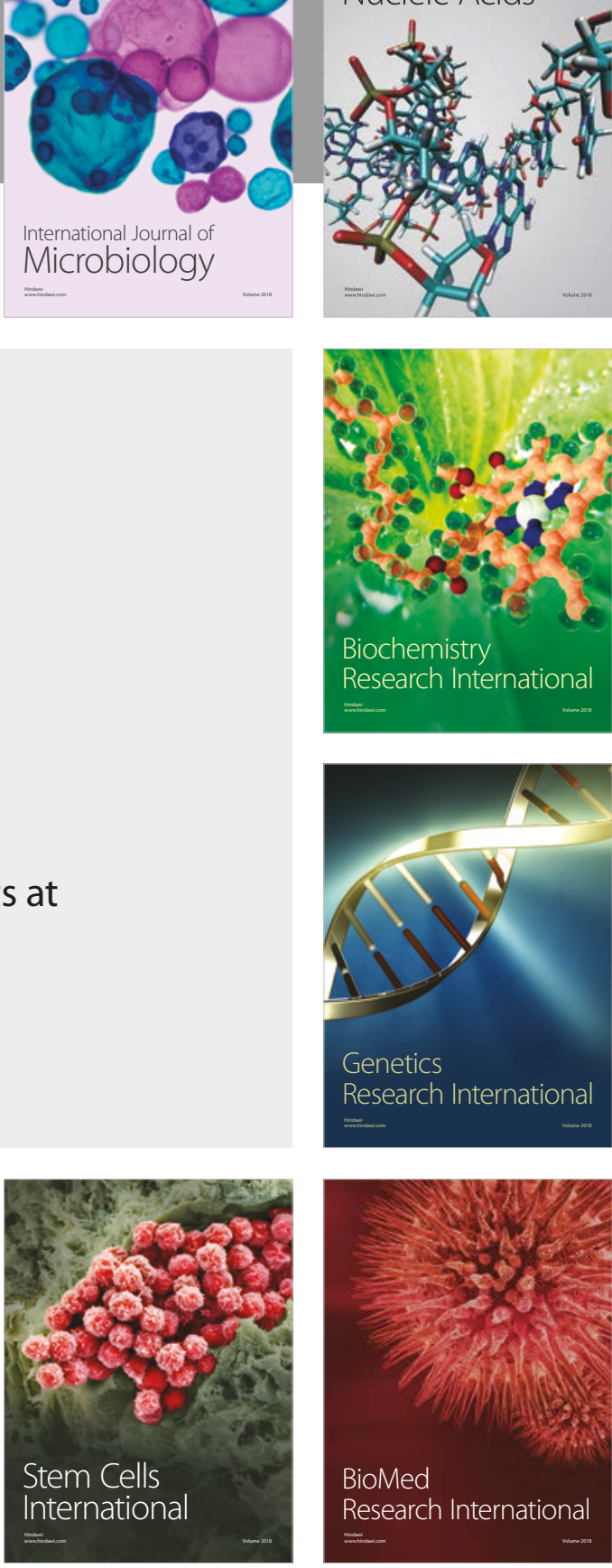
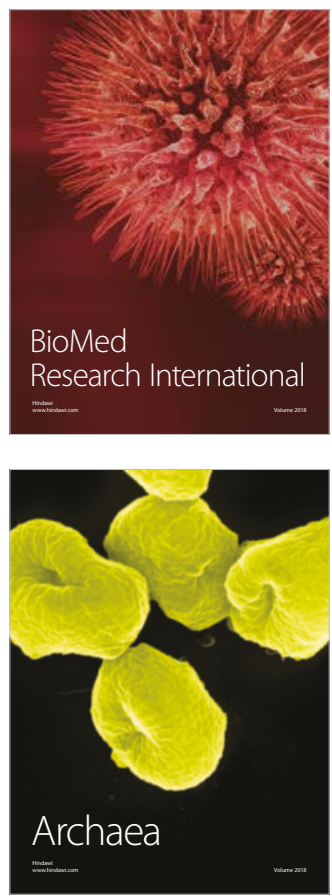